\title{
Carbon Dioxide and Temperature Influence Pollen Germination and Fruit Set in Cocoa
}

\author{
Madhu Aneja and Thomas Gianfagna \\ Department of Horticulture, Rutgers University, P.O. Box 231, New \\ Brunswick, NJ 08903
}

\section{Edward Ng and Ignacio Badilla \\ Information Services Group, EFFEM Services, Mount Olive, NJ 07828}

Additional index words. pollination, plant breeding, Theobroma cacao

\begin{abstract}
The causes of poor fruit set of cocoa (Theobroma cacao L.) in the greenhouse were studied by examining factors that may influence pollen germination. Hand pollination of cocoa flowers resulted in $\mathbf{4 5 . 8 \%}$ fruit set when flowers were pollinated within 3 hours of anthesis. Pollen germination did not occur until about 6 hours after pollination. Later pollinations ( 7 to 9 hours after anthesis) or earlier pollinations (16 to 18 hours before anthesis) did not lead to fruit set. Cocoa pollen did not germinate in vitro unless the excised flowers were incubated for 6 hours at $25 \mathrm{C}$ in closed vials. During the incubation period, $\mathrm{CO}_{2}$ accumulated to a final concentration of about $85 \mathrm{ml} \cdot \mathrm{liter} \mathrm{r}^{-1}$ as a result of respiration. Ethylene production was not detectable. Incubation of flowers with a $\mathrm{NaOH}$-saturated wick, to absorb $\mathrm{CO}_{2}$, prevented pollen germination in vitro. Incubation of flowers at $15 \mathrm{C}$ also prevented pollen germination in vitro at $25 \mathrm{C}$. Hand pollination of flowers 7 to 9 hours after anthesis or 16 to 18 hours before anthesis using $\mathrm{CO}_{2}$-incubated pollen resulted in about $10 \%$ fruit set. Enclosed pollinations in vivo, in which $\mathrm{CO}_{2}$ was allowed to accumulate, resulted in nearly $100 \%$ fruit set. The initial failure to set fruit from hand pollinations may result from poor or slow pollen germination. Moreover, $\mathrm{CO}$,-incubated pollen might be used to increase fruit set in cocoa by extending the effective pollination period.
\end{abstract}

Cocoa flowers begin to open with the separation of the sepals late in the afternoon; the following morning, 15 to $16 \mathrm{~h}$ later $(\approx 8: 00$ $\mathrm{AM})$, the completely open flowers contain dehisced anthers. The flowers remain on the tree for 1 to 2 days unless fertilization has occurred (Wellensiek, 1963). Pollen grains typically remain viable for $\approx 12 \mathrm{~h}$. In nature, pollination is effected by insects (Soetardi, 1950).

Cocoa breeding involves artificial pollinations, and for many reasons, including the narrow time period in which pollination must occur, the percentage of flowers that result

Received for publication 16 Dec. 1992. Accepted for publication 11 May 1992. New Jersey Agricultural Experiment Station Publication no. D12145-7-62, supported by state funds. We thank Joseph C. Goffreda for helpful discussions. The cost of publishing this paper was defrayed in part by the payment of page charges. Under postal regulations, this paper therefore must be hereby marked advertisement solely to indicate this fact. in a ripe fruit is considerably smaller than the number of pollinations (Wellensiek, 1963). To obtain a higher percentage of successful pollinations and, subsequently, fruit set, a more complete understanding of the pollination biology of cocoa is necessary. Failure of all attempts to germinate the pollen grains of cocoa in vitro led us to determine the possible effect of $\mathrm{CO}_{2}$ on this process, as there have been some reports in the literature that $\mathrm{CO}_{2}$ may enhance in vitro pollen germination in other species (Goss and Panchal, 1965; Malik and Dhaliwal, 1986; Sfakiotakis et al., 1972; Stanley et al., 1958; Thomas and Dnyansagar, 1975).

The objectives of the present study was to 1) investigate the physiological and anatomical causes of poor pollen germination and fruit set, 2) suggest methods to overcome these barriers, and 3) perhaps prolong the effective pollination period.

'Amelonado' cocoa trees were grown in a greenhouse at a night minimum of $20 \mathrm{C}$ and a day maximum of $35 \mathrm{C}$ in 20-liter plastic containers of a peat moss, vermiculite, aged pine bark, and perlite medium (Fafard Mix No. 50, C. Fafard, Springfield, Mass.). Trees were fertilized every 2 weeks with $200 \mathrm{mg}$ $15 \mathrm{~N}-6.6 \mathrm{P}-12.5 \mathrm{~K} / \mathrm{liter}$.

Freshly opened flowers were excised in the morning and stored in closed glass vials (seven flowers/7-ml vial) for $6 \mathrm{~h}$. The pollen grains were then tested in vitro for germination on a liquid medium (Brewbaker and Kwack, 1963) or a crushed stylar exudate using the hanging drop technique. During a 6-h incubation, the concentration and the rate of evolution of $\mathrm{CO}_{2}$ and ethylene were measured by gas chromatography. Minus $\mathrm{CO}_{2}$ controls were established by placing a $\mathrm{NaOH}$ saturated wick inside the vials to absorb the $\mathrm{CO}_{2}$ produced by the flowers. Vials containing flowers were kept at 15,25 , or $35 \mathrm{C}$ for $6 \mathrm{~h}$; the accumulation of $\mathrm{CO}_{2}$ was recorded hourly, and pollen germination was determined at room temperature $(24 \pm 2 \mathrm{C})$.

For in vivo pollen germination, the pistils were harvested at several time intervals after pollination, fixed in $11 \% \mathrm{Na}_{2} \mathrm{SO}_{3}$ for $24 \mathrm{~h}$, washed for a few minutes in distilled water, and the styles were then dissected open lengthwise under a dissecting microscope. Staining was performed with $0.1 \%$ aniline blue in $0.71 \mathrm{~g} \mathrm{~K}_{3} \mathrm{PO}_{4}$ (Bowerman, 1975), and the preparations were observed under a fluorescent microscope (Leitz, Wetzlar, Germany). For monitoring pollen tube growth in sectioned material, the harvested pistils were fixed in $10 \%$ acrolein at $0 \mathrm{C}$ for $24 \mathrm{~h}$. Following dehydration, the material was infiltrated and embedded in glycol methacrylate (Feder and O'Brien, 1968). Sections (2 $\mu$ ) were cut using glass knives, stained with

Table 1. Effects of temperature and $\mathrm{CO}_{2}$ concentration during the pregermination pollen storage period on in vitro cocoa pollen germination $(\mathrm{n} \geq 14)$.

\begin{tabular}{lcc}
\hline \hline $\begin{array}{l}\text { Incubation } \\
\text { temp }\left({ }^{\circ} \mathrm{C}\right)\end{array}$ & $\begin{array}{c}\mathrm{CO}_{2}{ }^{\mathrm{z}} \\
\left(\mathrm{ml} \cdot \cdot \mathrm{liter^{-1 }}\right)\end{array}$ & $\begin{array}{c}\text { Germination } \\
\text { at } 25 \mathrm{C}(\% \pm \mathrm{SE})\end{array}$ \\
\hline 15 & $0.05^{\mathrm{y}}$ & 0 \\
& 25 & $<1$ \\
25 & $0.05^{\mathrm{y}}$ & 0 \\
& 85 & $60 \pm 5$ \\
35 & $0.05^{\mathrm{y}}$ & 0 \\
& 105 & $60 \pm 7$ \\
\hline
\end{tabular}

${ }^{2}$ Carbon dioxide concentration (ml-liter $\left.{ }^{-1}\right)$ measured by gas chromatography after incubation of flowers in closed vials for $6 \mathrm{~h}$.

${ }^{y}$ Flowers were incubated in closed vials containing $\mathrm{NaOH}$-saturated wicks to absorb the $\mathrm{CO}_{2}$ produced. 
Table 2. Effect of pollen storage, $\mathrm{CO}_{2}$, and time of pollination on fruit set in cocoa.

\begin{tabular}{|c|c|c|c|}
\hline Treatment & $\begin{array}{l}\text { Time before (-A) or } \\
\text { after (+A) anthesis } \\
\text { (h) }\end{array}$ & $\begin{array}{c}\text { Fruit set }^{2} \\
(\%)\end{array}$ & $\mathrm{n}$ \\
\hline \multicolumn{4}{|l|}{ Morning pollinations } \\
\hline Control & $+\mathrm{A}, 1-3$ & $45.8 \mathrm{a}$ & 500 \\
\hline Enclosed pollination $\left(+\mathrm{CO}_{2}\right)$ & $+\mathrm{A}, 1-3$ & $96.3 \mathrm{~b}$ & 27 \\
\hline \multicolumn{4}{|l|}{ Afternoon pollinations } \\
\hline Control & $+\mathrm{A}, 7-9$ & $0 \quad \mathrm{~b}$ & 40 \\
\hline Pollen incubation $\left(+\mathrm{CO}_{2}\right)$ & $+A, 7-9$ & $12.9 \mathrm{a}$ & 70 \\
\hline Pollen incubation $\left(-\mathrm{CO}_{2}\right)$ & $+A, 7-9$ & $0 \quad \mathrm{~b}$ & \\
\hline Pollen incubation $\left(+\mathrm{CO}_{2}\right)$ & $-A, \quad 16-18$ & $12.5 \mathrm{a}$ & 2 \\
\hline
\end{tabular}

${ }^{2}$ Mean separation by orthogonal partitioning of the likelihood ratio chi square within time of pollination (morning or afternoon).

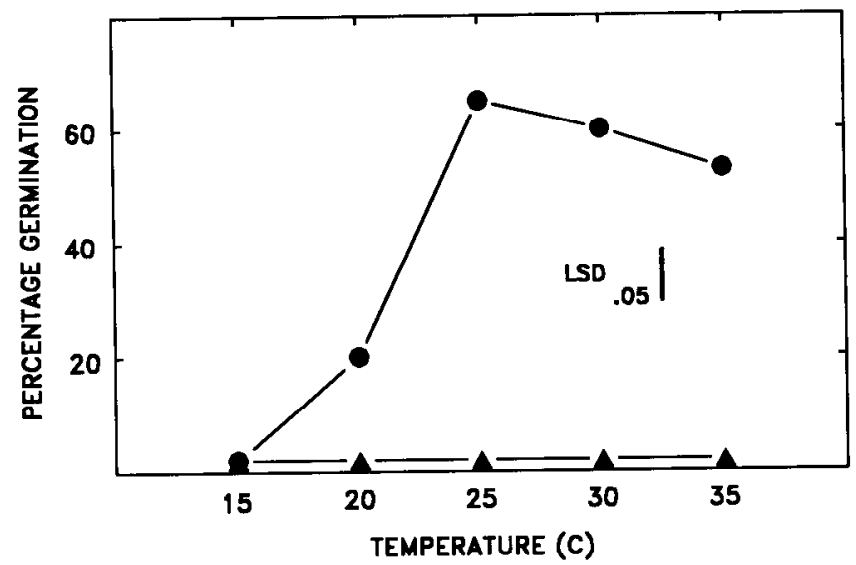

Fig. 1. Temperature and pregermination storage period effects on the in vitro germination of cocoa pollen $(\mathrm{n}=5)$. $(\bullet)$ Stored pollen $(6 \mathrm{~h}) ;(\boldsymbol{\Delta}-\boldsymbol{\Delta})$ fresh pollen.

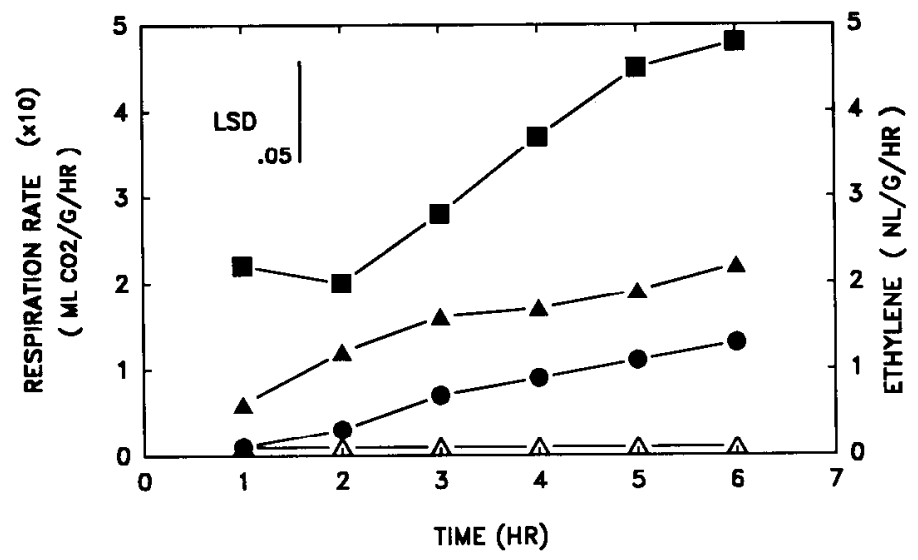

Fig. 2. Respiration of excised cocoa flowers at 15,25 , and $35 \mathrm{C}(\mathrm{n}=5$, with $\mathrm{LSD}$ ) and ethylene

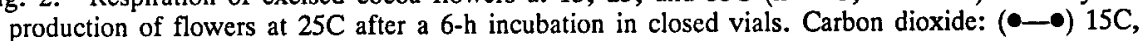
$(\Delta-\Delta) 25 \mathrm{C},(\boldsymbol{\square}-\mathbf{-}) 3 \mathrm{C}$; ethylene: $(\Delta-\Delta) 25 \mathrm{C}$.

$0.1 \%$ aniline blue (Bowerman, 1975), and observed under a fluorescent microscope.

Flowers were normally self-pollinated by hand at $\approx 8: 00$ to $9: 00 \mathrm{AM}$, when they are fully open. The staminodes were removed with a jeweler's forceps to gain easy access to the pistil. Anthers from flowers stored for $6 \mathrm{~h}$ in the vials were used to pollinate flowers in the afternoon, i.e., 7 to $9 \mathrm{~h}$ following their opening; pollinations also were done on flowers just beginning to open at $\approx 4 \mathrm{PM}$ (anthesis minus $16 \mathrm{~h}$ ). As controls, the pollen from flowers stored in vials containing $\mathrm{NaOH}-$ saturated wicks was also used to pollinate flowers in the afternoon.

For the enclosed pollinations, flowers were result in an increase in percent germination. \#en the flowers were stored for $8 \mathrm{~h}$, percent germination was $61 \% \pm 4 \%$. The optimum temperature range for germination was 25 to $30 \mathrm{C}$. Germination began after $0.5 \mathrm{~h}$ of incubation, and the pollen tubes reached a maximum length in about $1 \mathrm{~h}$. During $6 \mathrm{~h}$ of storage, there was no detectable ethylene produced by the flowers at any of the tested temperatures (Fig. 2). However, at $25 \mathrm{C}$ the concentration of $\mathrm{CO}_{2}$ in the vial rose to $\approx 80$ ml-liter-1 as a result of a respiration rate of $0.1 \mathrm{ml} \cdot \mathrm{g}^{-1} \cdot \mathrm{h}^{-1}$ (Fig. 2). Placing a $\mathrm{NaOH}-$ saturated wick in the vial containing excised flowers prevented the accumulation of $\mathrm{CO}_{2}$ and germination in vitro (Table 1). Incubating the vials with a higher concentration of $\mathrm{CO}_{2}\left(100 \mathrm{ml} \cdot \mathrm{liter}^{-1}\right)$ did not result in an increase in percent germination of pollen or allow shorter storage time.

There was a marked effect of the temperature at which the flowers were stored on both accumulation of $\mathrm{CO}_{2}$ and pollen germination (Table 2). At the three temperatures tested, the relationship between time and the accumulation of $\mathrm{CO}_{2}$ was linear (Fig. 2 ). At 25 and $35 \mathrm{C}$, the germination percentages were similar, and the vials accumulated 80 to $100 \mathrm{ml} \mathrm{CO} /$ liter. At $35 \mathrm{C}$, the cytoplasm of the pollen grains appeared shrunken. At $15 \mathrm{C}$, however, little germination $(16.6 \% \pm 2.3 \%)$ occurred, despite the accumulation of $20 \mathrm{ml} \mathrm{CO}_{2} /$ liter. Incubating the vials containing flowers with $100 \mathrm{ml} \mathrm{CO}_{2} /$ liter at $15 \mathrm{C}$ for $6 \mathrm{~h}$ failed to result in any further increase in germination (percent germination: $10.0 \% \pm 2.6 \%$ ).

In vivo pollen germination. Pollen grains germinated 5 to $6 \mathrm{~h}$ after pollination in vivo (Fig. 3A). The pollen tubes grew very fast, and within an hour they were present at the base of the style (Fig. 3B). Pollination of excised flowers resulted in $46.6 \% \pm 5.0 \%$ pollen germination after $6 \mathrm{~h}$; however, when the flowers were enclosed in vials after pollination, there was $100 \%$ pollen germination on the stigmatic surface. Enclosed pollinations of excised flowers with a $\mathrm{NaOH}$-saturated wick, for absorbing $\mathrm{CO}_{2}$, reduced pollen germination to $16.6 \% \pm 7.0 \%$.

Fruit set. Hand pollinations in the morning (anthesis plus 1 to $3 \mathrm{~h}$ ) resulted in nearly $50 \%$ fruit set, whereas pollinations in the afternoon (anthesis plus 7 to $9 \mathrm{~h}$ ) did not result in fruit set (Table 2). However, if pollen from stored flowers was used in pollinating the flowers during the afternoon, fruit set was low. If hand pollinations were done at the time the sepals began to separate (anthesis minus 16 to $18 \mathrm{~h}$ ) with pollen from stored flowers, fruit set was equally low (Table 2). Pollen grains from vials containing $\mathrm{NaOH}$-saturated wicks also germinated in vivo on flowers pollinated in the afternoon (anthesis plus 7 to $9 \mathrm{~h}$ ), but no fruit set was observed. Fruit set was greatly enhanced by enclosing pollinated flowers (anthesis plus 1 to $3 \mathrm{~h}$ ) in vials. Thus, nearly $100 \%$ of the flowers set fruit if $\mathrm{CO}_{2}$ was allowed to accumulate in vials containing attached flowers (Table 2).

To determine the reason for only $\approx 50 \%$ 


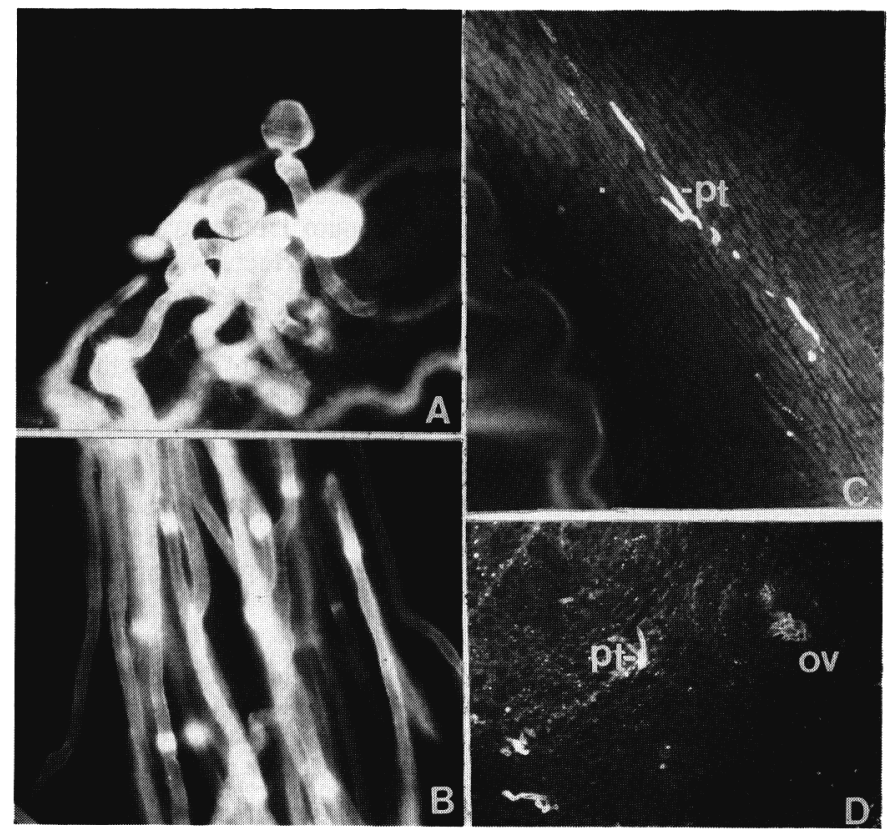

Fig. 3. In vivo cocoa pollen stained with $0.1 \%$ aniline blue. (A, B) Squash mounts; (C, D) $2 \mu$ glycol methacrylate sections. (A) Pollen grains germinating $6 \mathrm{~h}$ after pollination $(\times 270)$. (B) Pollen tubes $7 \mathrm{~h}$ after pollination, reaching the base of the style $(\times 340)$. (C) Pollen tubes $(\mathrm{pt})$ in the ovarian tissue $24 \mathrm{~h}$ after pollination $(\times 62.5)$. (D) Pollen tubes traversing the ovarian tissue $24 \mathrm{~h}$ after pollination, seen also near the tip of the ovule $(\mathrm{ov})(\times 400)$. fruit set for the morning pollinations (anthesis plus 1 to $3 \mathrm{~h}$ ), flowers were harvested 1 day after pollination and examined for evidence of pollen germination and pollen tube growth. In half of this sample, pollen germination either failed to occur or tube growth ceased at the top of the ovary, whereas in the rest of the sample, pollen tube growth through the style and the presence of pollen tubes in the ovary were clearly discernible (Fig. $3 \mathrm{C}$ and D)

In cocoa, our results indicate that $\mathrm{CO}_{2}$ treatment ( 80 to $100 \mathrm{ml} \cdot$ liter-1 for $6 \mathrm{~h}$ at $25 \mathrm{C})$ can significantly increase in vitro pollen germination. This effect is consistent with the results of others, cited earlier, for a variety of. species. The precise biochemical role played by $\mathrm{CO}$, in germination of pollen has not been ascertained.

Carbon dioxide may also play a role in pollen germination via the common "population effect," wherein there is an increase in germination with an increase in the number of pollen grains. As $\mathrm{CO}_{2}$ accumulates as a result of respiration, a greater percentage of the pollen is induced to germinate (Sfakiotakis et al., 1972). In cocoa, the source of increasing both in vitro pollen germination and fruit set is likely to be respiration. The possibility exists that pollen-stigma contact induces respiration and $\mathrm{CO}_{2}$ production. Given the same time, $6 \mathrm{~h}$, to germinate in vitro and in vivo, the storage interval in $\mathrm{CO}_{2}$ and the stigmatic surface might have similar roles to play in germination. Wellensiek (1963) reported using the stylar exudate for in vitro germination of cocoa pollen, although in our study, no germination was obtained using his method (data not shown). Cocoa pollen grains do not germinate at $25 \mathrm{C}$ if the flowers are the $\mathrm{CO}_{2}$ that we have found to be useful for that the pollen grains of cocoa require nearly
The coincidence between the percent fruit set (Table 2) and the percentage of pollinated flowers in which pollen germination and tube growth was evident suggests that absence of pollen germination may be a significant factor in limiting fruit set in the greenhouse. This hypothesis is strengthened by the finding that $\mathrm{CO}_{2}$ stimulates pollen germination in vitro (Table 1) and that enclosed pollinations, which accumulate $\mathrm{CO}_{2}$, yield nearly $100 \%$ fruit set (Table 2). Therefore, all treatments that increased pollen germination also increased fruit set.

The techniques of enclosed pollination and pollen incubation to increase fruit set seem worthy of practical testing as potential methods to increase cocoa crop yield and as aids to breeding programs.

\section{Literature Cited}

Bowerman, E.H. 1975. The development of male gametophyte in situ under selfing and cross-pollination \& six genotypes of tetraploid Vaccinium. PhD Diss., Rutgers Univ.. New Brunswick. N.J.

Brewbaker, J.L. and B.H. Kwack. 1963. The essential role of calcium ion in pollen germination and pollen tube growth. Amer. J. Bot. 50:859865

Buchanan, D.W. and R.H. Biggs. 1969. Peach fruit abscission and pollen germination as influenced by ethylene and 2-chloroethane phosphonic acid. J. Amer. Soc. Hort. Sci. 94:327-329.

stored at $15 \mathrm{C}$, even if a high level (100 ml-liter-') of $\mathrm{CO}_{2}$ has been injected into the vials. Perhaps the enzymatic activity involved in triggering germination is not activated at lower temperatures; however, this needs to be proved.

In our study, ethylene was apparently not involved in germination. We never detected ethylene levels above background in the vials. However, ethylene was shown to increase pollen germination in other species (Buchanan and Biggs, 1969; Search and Stanley, 1968).

Some of the pollinations in the afternoon (anthesis plus 7 to $9 \mathrm{~h}$ ) with $\mathrm{CO}_{2}$-treated pollen were successful, thus increasing the effective pollination period. Use of stored anthers to pollinate the young flower buds just as they began to open in the afternoon (anthesis minus 16 to $18 \mathrm{~h}$ ) also resulted in some fruit set. The latter is not a very practical method, as the flowers of cocoa are small and the buds have not opened completely at that time, so chances of damaging the style are great. Wellensiek (1963) obtained $3 \%$ fruit set by pollinating the young flowers in the evening (anthesis minus $12 \mathrm{~h}$ ) using the anthers from flowers picked in the morning.

In pollinations where flowers have been stored in vials containing $\mathrm{NaOH}$-saturated wicks, pollen grains do germinate in vivo, but there is no fruit set observed, as the pollen tubes do not seem to pass from the style to ovary. Thus, the factors preventing fruit set in cocoa during the afternoon manifest themselves subsequent to pollen tubes reaching the ovary. It is not, therefore, the lack of receptivity of the stigma or failure of pollen to germinate that poses a problem. The ovules still appear viable; however, they no longer may be able to attract the pollen tubes.

Feder, N and T.P. O'Brien. 1968. Plant microtechnique: Some principles and new methods. Amer. J. Bot. 5.5:123-142.

Goss, J.A. and Y.C. Panchal. 1965. Non-photosynthetic fixation of ${ }^{14} \mathrm{CO}_{2}$ by Ornithogalum caudatum pollen. Bioscience 15:38-39.

Malik, C.P. and A.S. Dhaliwal. 1986. Regulation of pollen germination and overcoming the incompatibility mechanism in Brassica campestris by $\mathrm{CO}_{2}$, p. 221-226. In: D.L. Mulcahy, G.B. Mulcahy, and E. Ottaviano (eds.). Biotechnology and ecology of pollen. SpringerVerlag, New York.

Nakanishi, T. and K. Hinata. 1973. An effective time for $\mathrm{CO}_{2}$ gas treatment in overcoming self incompatibility in Brassica. Plant Cell Physiol. 14:873-879.

Search, R.W. and R.G. Stanley. 1968. The effect of ethylene on pollen tube elongation. Plant Physiol. 43:S52. ley. 1972. Pollen germination and tube growth: Dependent on carbon dioxide and independent of ethylene. Plant Physiol. 49:963-967. contingency tables: Chi-square partitioning and other methods. Pyschol. Rpt. 33:343-348.

Soetardi, R.G. 1950. The importance of insects for the pollination of Theobroma cacao L.. p. 212-241. In: H. Toxopeus and P.C. Wessel (eds.). 1983. Archives of cocoa research. vol. 2. Royal Trop. Inst., Amsterdam, The Netherlands.

Stanley, R.G., L.C.T. Young, and J.S.D. Graham. 1958. Carbon dioxide fixation in germinating pine pollen (Pinus ponderosa). Nature 182:1462-1463.

Thomas, M.K. and V.R. Dnyansagar. 1975. Carbohydrate metabolism in pollen of Petunia nyctaginiflora during germination and tube growth. Indian J. Expt. Biol. 13:268-271.

Wellensiek, S.J. 1963. Observations on the flowering biology of cocoa, p. 182-195. In: H. Toxopeus and P.C. Wessel (eds.). 1983. Archives of cocoa research. vol. 2. Royal Trop. Inst., Amsterdam, The Netherlands.
Sfakiotakis, E.M., D.H. Simons, and D.R. Dil-

Shaffer, J.E. 1973. Testing specific hypotheses in 